Studia i materiały $\mathrm{z}$ dziedzictwa kulturowego Torunia i regionu,

t. 1: STARE I NOWE DZIEDZICTWO TORUNIA,

Toruń 2013

http://dx.doi.org/10.12775/SiMzDzKTiR_T1.2013.007

Izabella Brzostowska

(IZIK UMK, TORUŃ)

\title{
Przyczynki do dziejów budowlanych oraz wystroju malarskiego kościoła pw. św. Jana Chrzciciela i św. Jana Ewangelisty w Toruniu*
}

Fara Starego Miasta Torunia (il. 1), zgodnie z utrwalonymi w literaturze przedmiotu sądami, powstała w trzech zasadniczych fazach (które przyjęło się określać jako II, III i IV kościół), w miejscu wcześniejszej, murowanej świątyni (tzw. I kościół)1.

Jako pierwszy kościół przyjmuje się najstarsze założenie sakralne zlokalizowane w miejscu obecnie istniejącej świątyni, którego początek budowy nastąpić mógł najwcześniej po translokacji miasta na obecne miejsce w roku 1236. W starszej literaturze uchodził na ogół za prowizoryczny - drewniany ${ }^{2}$ - jednak w wyniku badań archeologicznych przeprowadzo-

* Badania, których wyniki są podstawą niniejszego artykułu, zostały przeprowadzone przez autorkę na zlecenie firmy RESTAURO Sp. z o.o. z siedzibą w Toruniu przy ul. Małe Garbary 4-6, prowadzącej prace konserwatorskie i restauratorskie przy wystroju korpusu nawowego i wnętrz kaplic w katedrze pw. św. Jana Chrzciciela i św. Jana Ewangelisty w Toruniu w latach 2010-2013; autorka dziękuje pani Prezes Małgorzacie DOBRZYŃSKIEJ-MUSIELA za umożliwienie publikacji wyników badań, a także konserwatorom - przede wszystkim Katarzynie Daniel, Aleksandrze Szarszewkiej i Annie Stelmaszak-Machowskiej - za owocną współpracę i cenne konsultacje.

1 Dyskusja na temat historii budowy kościoła Świętych Janów ma w literaturze długą tradycję i do dziś pozostaje nierozstrzygnięta. Podsumowanie stanu badań do 1995 r. patrz: Teresa MROCZKO, Elżbieta PILECKA, Andrzej WŁODAREK, [hasło:] Kościół par. p.w. śś. Jana Chrz. i Jana Ew., [w:] Architektura gotycka w Polsce, red. T. MROCZKO, M. ARSZYŃSKI, t. II: Katalog zabytków, red. A. WŁODAREK, Warszawa 1995, s. 240-241; podział na cztery zasadnicze etapy budowy i przemiany w architekturze kościoła zachowała Elżbieta PILECKA w artykule Kościót p.w. św. Jana Chrzciciela $i$ św. Jana Ewangelisty w Toruniu w okresie średniowiecza jako wizualizacja świadomości społecznej, [w:] Dzieje i skarby kościoła świętojańskiego w Toruniu. Materiały z konferencji przygotowanej przez Toruński Oddział Stowarzyszenia Historyków Sztuki w X rocznicę ustanowienia diecezji toruńskiej, 22-23 marca 2002 [dalej cyt. DZIEJE I SKARBY 2002], red. K. KLUCZWAJD, M. WOŹNIAK, Toruń 2002, s. 119-176, opierając datowanie poszczególnych faz na informacjach ze źródeł publikowanych, skonfrontowanych z wynikami badań architektonicznych oraz analizą formalną detalu architektonicznego i malarstwa ściennego. Patrz także: Liliana KRANTZ-DOMASŁOWSKA, Architektura, [w:] Bazylika katedralna Świętych Janów w Toruniu, red. M. BISKUP, Toruń 2003, s. 54-108; Christofer HERRMANN, Mittelalterliche Architektur im Preussenland. Untersuchungen zur Frage der Kunstlandshaft und -Geographie, Petersberg 2007, s. 760-762. Bardziej szczegółowy stan badań patrz: przypisy odnośnie do poszczególnych faz budowy.

2 Conrad STEINBRECHT, Thorn im Mittelalter, ein Beitrag zur Baukunst des Deutschen Ritterordens, Berlin 1885, s. 23; Johannes HEISE, Die Bau- und Kunstdenkmäler der Provinz Westpreussen, H. VI-VII: der Kreis Thorn, Danzig 1889, s. 240-266, tu s. 257; Jerzy FRYCZ, Gotycka architektura Torunia, [w:] Sztuka Torunia i Ziemi Chetmińskiej 1233-1815. Materiały sesji naukowej zorganizowanej dla uczczenia jubileuszu 750-lecia Torunia $w$ dniach 18-20 IV 1983 r., red. J. POKLEWSKI, Warszawa - Poznań - Toruń 1986, s. 31-53, tu s. 32-33. Teresa Mroczko 
nych w latach 1994-95 ustalono, że pierwszy kościół był budowlą murowaną z cegły (z użyciem cegły glazurowanej), wzniesioną najpewniej w formie wydłużonej, zamkniętej trójbocznie sali, przykrytej sklepieniem krzyżowym lub krzyżowo-żebrowym oraz radialnym w partii wschodniej ${ }^{3}$.

Kościół tzw. drugi przetrwał częściowo do dziś - z tego założenia pochodzi obecne prezbiterium oraz dolne partie ścian obwodowych korpusu i filarów międzynawowych. Wobec całkowitego niemal barku źródeł pisanych dotyczących najwcześniejszych dziejów świątyni, tezy na temat chronologii jego budowy są bardzo rozbieżne. Według Conrada Steinbrechta budowę w trwałym materiale podjęto około $1255 \mathrm{r}^{4}$. Johannes Heise, wnioskując z analogii do najstarszych części kościoła katedralnego i parafialnego w Chełmży oraz zamku, wieży ratusza i murów miejskich w Toruniu, datował początek budowy II kościoła po poł. XIII w., może ok. 1260 r., koniec zaś - ok. połowy XIV w. ${ }^{5}$. Tak przyjęte ramy chronologiczne dla murowanej świątyni zakwestionował Arthur Semrau, uznając je za zbyt późne. Przywołując argumenty przede wszystkim historyczne uznał, że budowa kościoła parafialnego w trwałym materiale możliwa była już w latach ok. 1250 do 1270 lub $1280^{6}$. Spostrzeżenia Semrau’a w dużej mierze okazały się słuszne, autor ten jednak, nie dysponując warsztatem badawczym historyka architektury, błędnie odniósł wnioski z analizy źródłowej do zachowanej częściowo do dziś świątyni. Kościół parafialny w trwałym materiale faktycznie powstał w zbliżonym do wyznaczonego przez tego badacza czasie, jego relikty zachowane są jednak pod ziemią ${ }^{7}$. Marek Kaszycki, w oparciu o analizę publikowanych źródeł, kontekstu historycznego i architektury kościoła, sytuuje pierwszą fazę jego budowy (identyfikowaną obecnie jako II kościół) w okresie: ostatnia tercja XIII w. - przed połową XIV w. ${ }^{8}$. Według Teresy Mroczko budowa II kościoła mogła być podjęta już ok. 1270 r. (chociaż nie są znane źródła, które mogłyby tak przyjęty początek budowy potwierdzić), ukończono ją natomiast przed 1330 r. ${ }^{9}$ W analogicznych ramach czasowych umieścił budowę II kościoła Jerzy Frycz $^{10}$. Przełom w dyskusji nad dziejami budowlanymi fary staromiejskiej przyniosły bada-

natomiast przyjęła, że pierwszy kościól, wzniesiony pomiędzy 1233 a 1257 r., był murowany, a informacji o jego formie architektonicznej powinny dostarczyć badania archeologiczne, patrz: Teresa MROCZKO, Architektura gotycka na ziemi chetmińskiej, Warszawa 1980, s. 15-17.

3 Lidia GRZESZKIEWICZ-KOTLEWSKA, Wstępne wyniki badań archeologicznych prowadzonych w kościele pw. Świętych Janów w Toruniu w latach 1994-1995, „Rocznik Toruński”, t. 23, 1996, s. 33-54; Lidia GRZESZKIEWICZ-KOTLEWSKA, Badania archeologiczne prezbiterium kościoła świętojańskiego w Toruniu w latach1994-1995, [w:] DZIEJE I SKARBY 2002, s. 103-117.

4 STEINBRECHT 1885, s. 23-24.

5 HEISE 1889, s. 257.

6 Arthur SEMRAU, Forschungen zur Baugeschichte der Johanniskirche in Thorn von 1250 bis 1500, „Mitteilungen des Coppernicus-Vereins für Wissenschaft und Kunst zu Thorn“, H. 21, 1913, s. 28-53, tu s. 28, 30.

7 Patrz: GRZESZKIEWICZ-KOTLEWSKA 1996; GRZESZKIEWICZ-KOTLEWSKA 2002.

8 Marek KASZYCKI, Trzynastowieczna architektura kościoła Św. Jana w Toruniu, [mps] Toruń 1961, Uniwersytet Mikołaja Kopernika, Wydział Sztuk Pięknych, Zakład Historii Sztuki Średniowiecznej i Nowożytnej, sygn. 51, s. 9-14, 74-75.

9 MROCZKO 1980, s. 75-76.

10 FRYCZ 1986, s. 37. 
nia archeologiczne przeprowadzone pod obecnym prezbiterium w latach 1994-1995 przez zespół pod kierunkiem Lidii Grzeszkiewicz-Kotlewskiej, w wyniku których odsłonięte zostały relikty wcześniejszej murowanej świątyni. Kościół ten - w opinii autorki badań funkcjonował przypuszczalnie przynajmniej 80 lat, więc kościół II datować można nie wcześniej niż na początek drugiej ćw. XIV w. ${ }^{11}$ Elżbieta Pilecka, powołując się na publikowane źródła i badania Teresy Mroczko, skonfrontowane $\mathrm{z}$ analizą formalną detalu architektonicznego, datowała budowę II kościoła na okres od pierwszego dziesięciolecia do lat 30. XIV w. ${ }^{12}$. Liliana Krantz-Domasłowska, podsumowując dotychczasowy stan badań, usytuowała budowę II kościoła w czasie: 1300-1320 (korpus) i 1320-30 (prezbiterium) ${ }^{13}$. Christofer Herrmann, przyjąwszy datę ścinki drzewa na więźbę chóru, określoną przez Aleksandra Koniecznego na rok 1302/03, za bliską końca budowy tej części świątyni, zamknął jej powstanie w czasie: ok. 1295/1305 - chór, do 1330 - korpus nawowy ${ }^{14}$. Reasumując: wydaje się prawdopodobne, że budowa tzw. II kościoła, podjęta w latach 90. XIII w. zamknęła się w ciągu pierwszej połowy wieku XIV. Jako pierwsze powstało prezbiterium, na co wskazują m.in. prowadzące doń trzy portale (jeden z zakrystii i dwa z zewnątrz), uzasadnione w sytuacji, gdy chór użytkowany był niezależnie, do czasu ukończenia korpusu nawowego. Za taką chronologią budowy przemawia również przewiązanie ścian pierwotnej zakrystii zarówno ze ścianą prezbiterium, jak i ze wschodnią ścianą północnej nawy bocznej korpusu, świadczące o równoczesnej ich budowie ${ }^{15}$. Wzniesiono więc chór wraz z zakrystią i wschodnimi ścianami naw bocznych (ok. 1290 do ok. 1310), który pełnił rolę kościoła do czasu zakończenia budowy korpusu ok. 1330 - 1340 r. Świątynia ta rekonstruowana jest jako niska trójnawowa, trójprzęsłowa hala ${ }^{16}, \mathrm{z}$ trójprzęsłowym prezbiterium oraz najprawdopodobniej wieżą zachodnią na przedłużeniu nawy głównej, wysuniętą w całym obwodzie przed fasadę ${ }^{17}$. Wnętrze przykrywały sklepienia krzyżowo-żebrowe i gwiaździste w prezbiterium oraz

11 GRZESZKIEWICZ-KOTLEWSKA 1996, s. 51-52, GRZESZKIEWICZ-KOTLEWSKA 2002, s. 115.

12 PILECKA 2002, s. 127; por. także: Elżbieta Pilecka, Budowanie i trwanie - karty ze średniowiecznych dziejów świątyni parafialnej Starego Miasta Torunia, obecnej katedry pw. św. Jana Chrzciciela $i$ św. Jana Ewangelisty, „Acta Uniwersitatis Nicolai Copernici”, Zabytkoznawstwo i Konserwatorstwo, t. 42, Toruń 2011, s. 402-429, tu s. 407, gdzie autorka przyjmuje koniec budowy korpusu pod koniec lat trzydziestych XIV w., natomiast ukończenie chóru ok. $1300 \mathrm{r}$.

13 Liliana KRANTZ-DOMASŁOWSKA, Dwa miasta - dwa kościoły, [w:] DZIEJE I SKARBY 2002, s. 195-218, tu s. 207, KRANTZ-DOMASŁOWSKA 2003, s. 74-75.

14 HERRMANN 2007, s. 761. Więźba dachowa nad prezbiterium jest wtórna, wykonano ją jednak przy użyciu elementów pochodzących z pierwotnej konstrukcji (informacja ustna uzyskana od Ch. Herrmanna).

15 Bożena ZIMNOWODA-KRAJEWSKA, Zakrystia kościoła świętojańskiego - próba rekonstrukcji faz budowy, [w:] DZIEJE I SKARBY 2002, s. 177-193, zwłaszcza s. 186-187.

16 Rekonstrukcja II kościoła jako hali została przyjęta przez większość badaczy, jedynie Steinbrecht wysunął tezę, że nawa główna była wyższa od naw bocznych (STEINBRECHT 1885, s. 25); ostatnio Christofer Herrmann rekonstruował korpus II kościoła w formie pseudobazyliki (HERRMANN 2007, s. 761-762).

17 Steinbrecht rekonstruuje korpus jako trójnawowy i czteroprzęsłowy, z wysuniętą wieżą na osi nawy głównej; STEINBRECHT 1885, s. 25. Heise dowodził, że korpus był trójprzęsłowy i najprawdopodobniej posiadał wysuniętą przed fasadę wieżę na przedłużeniu nawy głównej, którą po pożarze w $1351 \mathrm{r}$. obudowano, przedłużając nawy boczne o jedno przęsło w kierunku zachodnim; HEISE 1889, s. 246 i n., 257. Analogicznie rekonstruowali bryłę i układ przestrzenny II kościoła Marek Kaszycki (KASZYCKI 1961, s. 41, 43 i rysunek s. nlb., po s. 42) i Teresa Mroczko (MROCZKO 1980, s. 78, 96-97). 
krzyżowo-żebrowe na szerokich gurtach w korpusie; kształtki żeber sklepiennych w korpusie miały profil gruszkowy ze ściętym noskiem, z wałkiem i wklęską ${ }^{18}$. Architektura prezbiterium, a także poziom wykonania murów i jakość materiałów użytych do budowy korpusu wskazują na realizację przez wysoko wykwalifikowany warsztat i każą podejść ostrożnie do tez (np. Teresy Mroczko) o „trudnościach w finansowaniu budowy”.

Z ostatnich badań wynika ponadto, że wieża zachodnia drugiego kościoła najprawdopodobniej ujęta była aneksami (analogicznie jak na przykład w toruńskim kościele pw. Św. Jakuba). ${ }^{20}$ Świadczy o tym dekoracja malarska na ścianie południowej, pomiędzy obecnymi kaplicami Kopernikańską i Matki Boskiej Nieustającej Pomocy, w sposób nie budzący wątpliwości związana z drugim kościołem, która ciągnie się w kierunku zachodnim poza wyznaczoną w dotychczasowych badaniach granicę zachodnią świątyni (il. 2). Występ ściany pomiędzy ww. kaplicami (il. 3), interpretowany dotychczas przez większość badaczy jako ślad po ścianie poprzecznej, czyli zamykającej od zachodu drugi kościół ${ }^{21}$, jest pozostałością arkady łączącej nawę boczną z zamkniętą przestrzenią znajdującą się na jej przedłużeniu w kierunku zachodnim ${ }^{22}$. Przestrzeń tę można - jak się wydaje - interpretować jako aneks lub kaplicę przywieżową. Analogiczna sytuacja występuje w nawie północnej ${ }^{23}$, co skłania do rekonstrukcji zachodniej partii drugiego kościoła w formie masywu zachodniego.

$\mathrm{Na}$ dekoracyjną oprawę wnętrza korpusu, poza glazurowaną zieloną cegłą zdobiącą trzony filarów (il. 4), składało się także opracowanie malarskie. W najwcześniejszej fazie tworzył je malowany wątek ceglany: czerwona warstwa malarska nałożona bezpośrednio na ceglane lico ścian i spoinowanie podkreślone na biało. Ten sposób dekoracji występował zarówno w prezbiterium, jak i na wszystkich ścianach korpusu i na półfilarach przy ścianie zachodniej $^{24}$. Towarzyszyło mu malarskie opracowanie elementów detalu architektonicznego

18 Zachowały się fragmenty żeber sklepiennych II kościoła w strukturze obecnej budowli, w narożach korpusu nawowego: południowo-wschodnim i północno-wschodnim, które łącznie z zachowanymi strefami kapitelowymi półfilarów przyściennych, pozwalają na rekonstrukcję rysunku sklepień oraz profilu kształtki żebra sklepiennego.

19 MROCZKO 1980, s. 80.

20 Wskazał na to Jerzy Frycz, opierając się na interpretacji śladów w strukturze budowli; FRYCZ 1986, s. 39; także Elżbieta Pilecka przyjęła za możliwą rekonstrukcję partii zachodniej w formie wieży ujętej aneksami, do czego przesłanką są analogiczne rozwiązania w budowlach Szlezwiku-Holsztyna, skąd - zdaniem autorki - mogła pochodzić strzecha budowlana czynna przy realizacji toruńskiej fary staromiejskiej: PILECKA 2002, s. 133.

21 HEISE 1889, s. 247, KASZYCKI 1961, s. 43; MROCZKO 1980, s. 78.

22 Poza wspomnianą wyżej dekoracją malarską, za taką interpretacją przemawia zachowane pod tynkiem ceglane lico, odsłonięte w trakcie badań na omawianym występie ściany, które przeczy jego interpretacji jako skutej ściany poprzecznej; skuta jest dopiero górna partia, od miejsca gdzie zaczynał się łuk arkady.

$23 \mathrm{Na}$ odcinku ściany północnej pomiędzy obecnymi kaplicami św. Barbary i św. Józefa nie stwierdzono występowania dekoracji malarskiej z II kościoła, za wyjątkiem czerwonej monochromii z białym spoinowaniem bezpośrednio na licu ceglanym, ponieważ - z uwagi na zachowane w tym miejscu nowożytne warstwy malarskie - nie zdecydowano się na wykonanie większych odkrywek. Zachowała się tu natomiast, analogicznie jak w nawie południowej, dolna partia arkady, łączącej pierwotnie nawę północną z północnym aneksem przywieżowym, znajdującym się na jej przedłużeniu w kierunku zachodnim. Fragment skutego łuku arkady jest tu wyraźnie czytelny i został odnotowany już przez Heisego (HEISE 1889, s. 246-247) i następnie przez Marka Kaszyckiego (KASZYCKI 1961, s. 43), jednak bez konsekwencji w odniesieniu do rekonstrukcji zachodniej partii korpusu nawowego II kościoła.

24 Odsłonięty w trakcie badań stratygraficznych na fragmentach muru przy łukach arkad łączących nawy boczne z kaplicami oraz na półfilarach przyściennych i pierwotnych półfilarach zachodnich. 
i sklepień. Strefy kapitelowe filarów i półfilarów przyściennych, wykonane ze sztucznego kamienia (gipsu jastrychowego), w formie profilowanych gzymsów, posiadały bardzo prostą dekorację, składającą się z poziomych pasów podkreślających profilowanie, w kolorach: czerwonym, błękitnym i zielonym, przy czym na poszczególnych elementach występują po dwa kolory ${ }^{25}$ (il. 5, 6).

Sklepienia otrzymały dekorację wzdłuż łuków tarczowych oraz na gurtach, w formie bardzo uproszczonych czerwonych czołganek oraz wąskich pasów - czerwonych i szarych (il. 7, 8). Żebra sklepienne były dwubarwne: część kształtki o profilu gruszkowym była w kolorze błękitnym, a pozostała część żebra, bliższa wysklepki - czerwona ${ }^{26}$ (il. 9).

Jeszcze w XIV w., a w każdym razie przed podjęciem decyzji o podwyższeniu kościoła, świątynia otrzymała drugi wystrój malarski, być może związany z budową północnego rzędu kaplic i przebiciem w związku z tym arkad do tychże kaplic w ścianie północnej. Zachowane warstwy malarskie i wykonane odkrywki nie pozwalają na wiarygodną rekonstrukcję pełnego obrazu tych dekoracji, jednak przekonują, że były wykonane według jednolitej koncepcji dla całego korpusu nawowego. Otynkowano wówczas ściany, łuki arkad do kaplic, półfilary przyścienne i najprawdopodobniej także filary międzynawowe. W miejsce uproszczonych czołganek wzdłuż łuków tarczowych i na gurtach sklepień wprowadzono dekorację w formie suchych liści w kolorach ciemnej czerwieni (czerwień żelazowa) i błękitu (azuryt) (il. 2, 10); żebra sklepienne pomalowano w poprzeczne szerokie pasy czerwone i błękitne. Nie wprowadzono natomiast drugiej warstwy malarskiej na strefy kapitelowe filarów i półfilarów. Być może elementem tego wystroju malarskiego była także dekoracja romboidalna z elementami heraldycznymi w dolnych partiach ściany wschodniej.

Odrębnym zagadnieniem jest dekoracja malarska pierwotnego półfilara przy ścianie wieży po stronie południowej (il. 11). Przykrywa ona malowany wątek ceglany z pierwszej fazy i wydaje się być dziełem autonomicznym. Jest to wić roślinna o dominującym kolorze zielonym z elementami w kolorach pomarańczowym i żółtym. Zakres jej występowania, ograniczony do ścian pierwotnego półfilara i wysokością odpowiadający filarom międzynawowym drugiego kościoła pozwala wiązać wić z wystrojem malarskim niskiej hali.

Elementem związanym raczej z wystrojem kaplicy niż całego korpusu nawowego wydaje się być dekoracja malarska zlokalizowana na pierwszym od wschodu półfilarze w nawie południowej - o motywach roślinnych, z elementami nawiązującymi do maswerku (rybie pęcherze), utrzymana w kolorystyce czerwonej i zielonej ${ }^{27}$ (il. 12).

Ostatnią fazą wystroju malarskiego drugiego kościoła wydaje się być wielki wątek, wprowadzony jedynie na ścianę wschodnią i prawdopodobnie zachodnią (zachowany na obu pierwotnych półfilarach zachodnich; na obecnym filarze po stronie południowej przykrywa

25 Warstwa malarska została naniesiona na cienką, czystą pobiałę, z którą jest mocno związana, sztuczny kamień pod pobiałą także nie nosi śladów zabrudzeń, co prowadzi do wniosku, że mamy do czynienia z pierwotną dekoracją malarską.

26 Zachowane w strukturze obecnej budowli ślady pierwotnego wystroju malarskiego nie dają odpowiedzi na pytanie o ewentualną dekorację wysklepek, np. wzdłuż żeber.

$27 \mathrm{~W}$ trakcie prac konserwatorskich nie natrafiono na analogiczną dekorację, co jednak nie pozwala $\mathrm{z}$ całą pewnością wykluczyć jej istnienia. 
wspomnianą wyżej wić roślinną). Tworzą go szare „ciosy” z białą, podkreśloną czerwonym paskiem spoiną (il. 13).

Faza budowy fary staromiejskiej zwana „trzecim kościołem” w opinii większości badaczy obejmować miała prace związane z jej odbudową po pożarze miasta, który miał miejsce w $1351 \mathrm{roku}^{28}$. Zakres tych prac pozostaje jednak daleko idącą hipotezą. W literaturze przedmiotu utrwalił się pogląd jakoby w omawianej fazie odbudowano wieżę, rozbudowując jednocześnie korpus nawowy w kierunku zachodnim o jedno przęsło ${ }^{29}$. Johannes Heise przypuszczał ponadto, że na skutek wspomnianego pożaru zawaliły się sklepienia korpusu ${ }^{30}$, co z kolei skłoniło kolejnych badaczy do wysunięcia tezy o przekształceniu w drugiej połowie XIV w. pierwotnej hali na pseudobazylikę $e^{31}$ lub bazylikę ${ }^{32}$. Zasadniczy etap prac - zgodnie $\mathrm{z}$ dominującą $\mathrm{w}$ literaturze przedmiotu opinią - zamknięto $\mathrm{w} 1388 \mathrm{roku}^{33}$, natomiast wieża ukończona została dopiero na początku XV wieku³4.

Stan zachowania ceglanego lica ścian w obrębie niskiej hali, jak też znajdujących się na nich warstw malarskich, każe jednak odrzucić hipotezę jakoby na skutek pożaru w 1351 roku korpus nawowy świątyni uległ bardzo poważnym zniszczeniom, łącznie z zawaleniem się sklepień. Czarny osad widoczny jedynie w dolnych partiach ścian i filarów może być skutkiem działania ognia, jednak skala zniszczeń nie jest na tyle duża, by mogła świadczyć o katastrofie budowlanej ${ }^{35}$. To z kolei stawia pod znakiem zapytania daleko idącą przebudo-

28 Ten etap dziejów budowlanych świątyni wyznaczony został w głównej mierze w oparciu o zapis źródłowy z 1361 r., w którym jest mowa o wsparciu finansowym udzielonym przez biskupa chełmińskiego Jana Schadlanda zniszczonemu przez pożar kościołowi świętojańskiemu (Urkundenbuch des Bisthums Culm, T. 1: Das Bisthum Culm unter dem Deutschen Orden 1243-1466, Hg. Carl Peter WOELKY, Danzig 1885, Nr. 308).

29 HEISE 1889, s. 256 i n.; SEMRAU 1913, s. 34; KASZYCKI 1961, s. 15; FRYCZ 1986, s. 46 i n.; PILECKA 1987, s. 113; PILECKA 2002, s. 140, 143; KRANTZ-DOMASŁOWSKA 2003, s. 82-84. W niniejszym artykule pominięto kwestię budowy kaplic wzdłuż północnej i południowej ściany korpusu, jako że w odniesieniu do chronologii ich powstawania nie sformułowano nowych wniosków. Przyjmuje się, że północny rząd kaplic zaczęto wznosić w latach czterdziestych XIV w. (ich budowa łączy się więc z omawianą fazą przekształceń architektury kościoła), kaplice południowe powstały na początku XV w.; MROCZKO, PILECKA, WŁODAREK 1995, s. 241.

30 HEISE 1889, s. 256.

31 MROCZKO 1980, s. 80, 209.

32 PILECKA 2002, s. 140, 143; autorka nie rozstrzygnęła czy odbudowana po pożarze świątyni otrzymała bazylikowy, czy pseudobazylikowy układ.

33 Takie datowanie zakończenia omawianego etapu prac wynika z interpretacji zapisu źródłowego, w którym mowa jest o pozwoleniu na pochówek w kościele ciał tych, którzy przyczynili się do odbudowy i wyposażenia świątyni (dokument cytuje Albert VOIGT, Thorner Denkwürdigkeiten von 1345-1547, „Mitteilungen des Coppernicus-Vereins für Wissenschaft und Kunst zu Thorn”, H. 13, 1904, s. 14). Zapis ten nie musi jednak wiązać się z zakończeniem prac budowlanych. Przeciwnie - może świadczyć o próbie zmobilizowania ludzi do ofiarności na cele budowy, za co nagrodą ma być prestiż pochówku w świątyni po śmierci i dowodzić tym samym trwania prac - nie zaś ich zakończenia, zwłaszcza, że przywilej został potwierdzony w 1391 r. (patrz: VOIGT 1904, s. 19). O ile zezwolenie na pochówek w kościele osób za życia wspierających jego budowę w przypadku nowo wznoszonej świątyni jest przesłanką za bliskim raczej zakończeniem prac (nie można grzebać zmarłych na placu budowy), o tyle w przypadku odbudowy częściowo zniszczonej świątyni, w której np. wnoszona jest wieża zachodnia, utożsamianie takiego przywileju z zakończeniem budowy wydaje się nadinterpretacją (trwające prace nie wykluczają możliwości grzebania zmarłych w kościele).

34 Wskazuje na to zapis źródłowy, zgodnie z którym w 1403 r. wieżę pokryto ołowiem (VOIGT 1904, s. 32; patrz także SEMRAU 1913, s. 43).

35 Trudno przyjąć, że runęły sklepienia korpusu a zachowała się w dobrym stanie współczesna im dekoracja 
wę kościoła w drugiej połowie XIV wieku i nadanie jej bazylikowej lub pseudobazylikowej formy; poza otworem w ścianie tęczowej, który może być świadectwem nie zrealizowanych planów, nie ma w strukturze obecnej budowli śladów wskazujących na jej przebudowę do formy bazyliki lub pseudobazyliki ${ }^{36}$.

Kościół tzw. czwarty to zachowana do dziś budowla, powstała w kilku etapach w wieku XV, na zrębie świątyni wcześniejszej. Wzniesiono wówczas masywną wieżę zachodnią, wtopioną częściowo w obręb korpusu i ujętą wysokimi aneksami (kaplicami przywieżowymi) oraz podwyższono znacznie korpus nawowy, nadając mu formę wysokiej hali, nadbudowując ściany i filary międzynawowe. Odnośnie do datowania faz budowy czwartego kościoła istnieją różne poglądy. Większość badaczy przyjmuje, że w latach 1407-1433 wzniesiono wieżę ${ }^{37}$, natomiast podwyższenie i zasklepienie korpusu przypada na okres 1468-1473 ${ }^{38}$. Jako datę zakończenia głównych prac budowlanych przyjmuje się rok 1473 (inskrypcja we wnętrzu, na zachodniej ścianie nawy północnej, dotycząca ukończenia sklepień). O ile dobrze udokumentowany źródłowo czas powstania wieży nie budzi wątpliwości, to dyskusyjna jest zarówno data podjęcia decyzji o podwyższeniu korpusu nawowego do obecnej wysokości, jak też czas realizacji tego przedsięwzięcia.

W odniesieniu do pierwszej kwestii wydaje się - na co wskazał już m.in. Artur Semrau - że tak monumentalna wieża nie mogła być przewidziana do niskiej hali w jej pierwotnej formie i wiązać ją należy raczej z planami podwyższenia korpusu. Dodatkowym argumentem jest wysoka nisza we wschodniej ścianie wieży, która kończy się na wysokości obecnych sklepień $^{39}$. W odniesieniu do chronologii rozbudowy korpusu, w świetle ostatnich badań wydaje się prawdopodobne, że powzięte u progu XV wieku plany podwyższenia kościoła zrealizowano w co najmniej dwóch fazach, w znacznym odstępie czasu. W pierwszym eta-

malarska.

36 Przyjmując wspomniany otwór w ścianie tęczowej za świadectwo funkcjonowania świątyni w formie bazyliki lub pseudobazyliki (por. MROCZKO 1980, s. 80), za element tak ukształtowanego wnętrza uznać należy również ścianę, w której ów otwór się znajduje. Powinna więc ona nosić, powyżej obecnego łuku tęczowego, ślad po sklepeniu (opór sklepienny), którego nie ma.

37 W 1406 r. zawaliła się jedna trzecia część wieży, którą następnie rozebrano (VOIGT 1904, s. 37). W 1407 r. położono kamień węgielny pod budowę nowej wieży (o czym świadczy inskrypcja na nadprożu zachodniego portalu; patrz także VOIGT 1904, s. 37). Szczegółowe informacje źródłowe, dokumentujące kolejne etapy wznoszenia wieży, przytacza Arthur Semrau (Arthur SEMRAU, Der Bau des Kirchturms zu S. Johann in Thorn, „Mitteilungen des Coppernicus-Vereins für Wissenschaft und Kunst zu Thorn”, H. 18, 1910, s. 27-39; SEMRAU 1913, s. 43-46).

38 Takie datowanie ostatniego znaczącego etapu w dziejach budowlanych fary staromiejskiej zaproponował Conrad Steinbrecht, opierając się na zapisie źródłowym z miejskiej księgi czynszów pod datą 1468: „Item zu wissen allen und jeghlichen und zukünftigen die der Ersame Rath zu der Kirche S. Johannis zu Vorweser kiest und setzet, dass die fleyssiglichen lassen zusehen zu den Rinnen über der mittelkirchen wenn es ist geschehen, do man die pfeiler ufftrieb mit dem Gewelbe do hat der Zimmermann versehen mit den balken und hat die versniten das die uff die Mauerlatte nicht kunden reichen sunder man muste sie uff eichen Klötzer legen domit sie vorlenget worden. Dergleichen man och zu den dechern wol zusche uff das der Kirche und den gewölben keyn schade geschee in zukommenden zeiten. (cytuję za: STEINBRECHT 1885, s. 24). Interpretacja Steinbrechta została następnie przyjęta przez większość badaczy, patrz: SEMRAU 1913, s. 47 i n.; MROCZKO 1980, s. 80; PILECKA 1987, s. 114 i n.; MROCZKO, PILECKA, WŁODAREK 1995, s. 241. Odrębne stanowisko zajął Johannes Heise, przyjmując zakończenie budowy korpusu na 1437 r. (HEISE 1889, s. 258) oraz Jerzy Frycz, który podjęcie rozbudowy hali sytuuje przed 1433 r. (FRYCZ 1986, s. 49).

39 SEMRAU 1913, s. 49; patrz także PILECKA 1987, s. 116. 
pie, równocześnie z budową wieży, wzniesiono mury obwodowe korpusu, podwyższono filary międzynawowe i całość przykryto dachem ${ }^{40}$. Lico nadmurowanych ścian pozostawiono nie otynkowane, natomiast otynkowano glify okienne. W takiej formie kościół pozostawał przez dłuższy okres czasu, do momentu założenia sklepień w latach siedemdziesiątych $\mathrm{XV}$ wieku. Wówczas ściany otynkowano i pokryto pobiałą; gruba warstwa brudu zalegająca pomiędzy pierwotną warstwą tynku glifów okiennych a nachodzącą nań warstwą tynku zaciągniętego ze sklepień, a także warstwa brudu na ceglanym licu nadbudowanych partii ścian, wskazują na długą przerwę dzielącą obie fazy budowy. W tym kontekście ponowna analiza znanego źródła z 1468 roku $^{41}$ prowadzi do wniosku, że mowa jest w nim o kładzeniu przez cieślę konstrukcji drewnianej na istniejących już murach i filarach nawy środkowej, w celu wzniesienia sklepienia, a następnie o planowanym położeniu więźby pod dach i zaopatrzeniu tego ostatniego w rynny, kiedy już zostanie skonstruowany ${ }^{42}$. Dodatkowym argumentem za tak przyjętą chronologią budowy wysokiej hali jest odsłonięta podczas prac konserwatorskich inskrypcja na wschodniej ścianie nawy głównej:

\section{ANNO D[OMI]NI 1433. IN VIGILIA S. LAURENTII. HIC FORNIX PERFECTUS EST.//ANNO D[OMI]NI 1730. TEMPLUM HOC RENOVATUM EST ${ }^{43}$.}

Podsumowując należy stwierdzić, że badania towarzyszące pracom konserwatorskim prowadzonym w latach 2010-2013 w kościele Świętojańskim w Toruniu w konfrontacji ze znanymi źródłami i dotychczasowym stanem badań pozwoliły na sformułowanie nowych wniosków zarówno w odniesieniu do chronologii budowy świątyni, jak też do jej pierwotnego wystroju malarskiego. W świetle tychże badań drugi kościół jawi się jako trójnawowa, trójprzęsłowa hala, z trójprzęsłowym (istniejącym) prezbiterium i wieżą zachodnią ujętą aneksami. Oprawę malarską wnętrza korpusu w najwcześniejszej fazie tworzył malowany wątek ceglany, któremu towarzyszyło bardzo proste opracowanie malarskie elementów detalu architektonicznego i sklepień, o gamie kolorystycznej zawężonej do czerwieni, zieleni i błękitu. Drugą, jeszcze czternastowieczną oprawę malarską korpusu (rozpoznaną w znacznie mniejszym zakresie) z dużą dozą ostrożności rekonstruować można jako bardziej rozbudowaną (w miejsce prostych czołganek z pierwszej fazy wprowadzono bardziej złożone i eleganckie w formie motywy roślinne) i mniej spójną - pojawiają się dekoracje indywidualne (np. wić roślinna na zachodnim półfilarze po stronie południowej), nie powiązane

40 Zaproponowana przez Lilianę Krantz-Domasłowską „kompromisowa” hipoteza, zgodnie z którą równocześnie $\mathrm{z}$ budową masywu zachodniego podwyższono ściany zewnętrzne korpusu i go zadaszono, a w latach 1468-1473 wyburzono stare sklepienia, podwyższono filary i arkady międzynawowe oraz przesklepiono wnętrze (KRANTZ-DOMASŁOWSKA 2003, s. 96) jest trudna do pogodzenia z historią technik budowlanych: w XV w. niemożliwym było wykonanie więźby dachowej o rozpiętości $25 \mathrm{~m}$, która trzymałaby się jedynie na murach zewnętrznych, bez podpór.

41 Patrz przypis38.

42 Dziękuję Prof. Jackowi Tylickiemu za pomoc w tłumaczeniu dokumentu.

43 Inskrypcja pochodzi z czasu XVIII-wiecznej renowacji kościoła, jednak z dużym prawdopodobieństwem można przyjąć, że jej część dotycząca okresu średniowiecza oparta zastała na istniejącej tu wówczas pierwotnej inskrypcji. Patrz także: Julius Emil WERNICKE, Die Kirchen der Stadt Thorn und ihres Gebietes, Archiwum Państwowe w Toruniu, Kat. II, sygn. X 25, s. 18 (stara pag., s. 13), SEMRAU 1913, s. 37. 
z programem malarskim całości wnętrza.

Faza przekształceń architektury świątyni, określana w literaturze jako tzw. kościół trzeci i przypadająca na drugą połowę XIV wieku, wydaje się sprowadzać do odbudowy zniszczonej pożarem partii zachodniej - wieży i być może aneksów przywieżowych oraz budowy kaplic wzdłuż ścian korpusu nawowego. Nie ma natomiast przekonujących dowodów na to, że trzeci kościół miał formę bazyliki lub pseudobazyliki. Piętnastowieczna przebudowa świątyni, w wyniku której otrzymała ona formę wysokiej, zachowanej do dnia dzisiejszego hali, przebiegała w dwóch zasadniczych fazach. W pierwszym etapie, trwającym do lat trzydziestych XV wieku, wzniesiono masyw zachodni z wieżą, mury obwodowe korpusu, podwyższono filary międzynawowe i całość przykryto dachem. W drugiej fazie, w latach siedemdziesiątych XV stulecia, wnętrze przesklepiono.

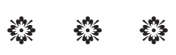

\section{Notes on building history and painted decoration in the church of St. John the Baptist and St. John the Evangelist in Toruń}

Since 2010 major restoration works are being carried out in the parish church of the Torun Old Town. Research conducted in correlation with these works leads to new conclusions with regard to building history of the church as well as its painted decoration.

Existing building has been created in two major phases, in a location of an earlier, brickbuilt church (the so-called first church). The so-called second church, begun probably in the 1290 s, has been completed during the first half of the fourteenth century. It was a low, threebay-deep and three-bay-wide hall church with a three-bay long chancel (still extant) and a western tower flanked by annexes, similarly as in St. James' church in Torun. In the second half of the fourteenth century chapels along southern and northern walls of the aisles have been added.

Present day elevated hall church has been created by construction of a new, monumental western tower, as well as by rising of the nave main body over walls and piers of the so-called second church (which are still extant). Works in the nave main body have been carried in two major phases. The first one, carried out between 1407 and 1433, included erection of a new western tower, rising of church piers and walls as well as construction of a roof. Vaults have been created during the second phase, which took place in the 1470s.

Early painted decoration in the interior of the nave main body of the second church consisted of imitation of brick masonry, as well as colouring applied on architectonic details and vaults. Capitals of piers and half-piers (made of artificial stone) were decorated with red, blue and green horizontal stripes accentuating their tectonics. Vaults were ornamented with simplified crockets as well as red and grey stripes along wall arches and transverse arches. Ribs were coloured with horizontal stripes, with their inner part painted blue and the outer part, placed closer to vault, painted red. 
Later in the fourteenth century the church has been redecorated. Interior was whitewashed, simplified crockets have been replaced with dark red and blue floral motives. Vault ribs were decorated with broad transverse stripes coloured red and blue. Possibly, rhomboidal pattern with heraldic motives in the lower part of the eastern wall formed part of the same decorative scheme. 


\section{SPIS ILUSTRACJI:}

1. Toruń, kościół pw. Św. Jana Chrzciciela i Św. Jana Ewangelisty, widok od pd.-zach., fot. M. GałązkaNikonov, $2011 \mathrm{r}$.

2. Toruń, kościół pw. Św. Jana Chrzciciela i Św. Jana Ewangelisty, korpus nawowy, ściana południowa, dekoracja malarska tzw. II kościoła, 1 poł. XIV w.: 1 faza - czołganki, 2 faza - liście, fot. I. Brzostowska, $2011 \mathrm{r}$.

3. Toruń, kościół pw. Św. Jana Chrzciciela i Św. Jana Ewangelisty, korpus nawowy, ściana południowa - fragment pierwotnej arkady łączącej nawę południową z aneksem przywieżowym, fot. I. Brzostowska, $2012 \mathrm{r}$.

4. Toruń, kościół pw. Św. Jana Chrzciciela i Św. Jana Ewangelisty, korpus nawowy, filar środkowy w rzędzie północnym, partia dolna pochodząca z II kościoła - dekoracja z zielonej glazurowanej cegły, fot. I. Brzostowska, 2011 r.

5. Toruń, kościół pw. Św. Jana Chrzciciela i Św. Jana Ewangelisty, korpus nawowy, ściana północna, strefa kapitelowa półfilara pomiędzy obecnymi kaplicami Św. Ignacego Loyoli i Św. Józefa, dekoracja malarska II kościoła, fot. I. Brzostowska, $2011 \mathrm{r}$.

6. Toruń, kościół pw. Św. Jana Chrzciciela i Św. Jana Ewangelisty, korpus nawowy, strefa kapitelowa filara pierwszego od wschodu w rzędzie północnym, dekoracja malarska II kościoła, fot. I. Brzostowska, $2011 \mathrm{r}$.

7. Toruń, kościół pw. Św. Jana Chrzciciela i Św. Jana Ewangelisty, korpus nawowy, ściana południowa, fragment dekoracji malarskiej II kościoła (1 faza) odsłonięty na skutym spływie sklepiennym, ponad półfilarem pomiędzy obecnymi kaplicami Św. Stanisława Kostki i Matki Boskiej Nieustającej Pomocy, fot. I. Brzostowska, 2011 r.

8. Toruń, kościół pw. Św. Jana Chrzciciela i Św. Jana Ewangelisty, korpus nawowy, dekoracja malarska II kościoła (1 faza) zachowana nad łukiem tęczowym (stan po konserwacji), fot. I. Brzostowska, $2012 \mathrm{r}$.

9. Toruń, kościół pw. Św. Jana Chrzciciela i Św. Jana Ewangelisty, korpus nawowy, spływ sklepienny II kościoła z zachowaną pierwotną dekoracją malarską, fot. I. Brzostowska, $2011 \mathrm{r}$.

10. Toruń, kościół pw. Św. Jana Chrzciciela i Św. Jana Ewangelisty, korpus nawowy, nawa główna, ściana wschodnia, fragment dekoracji malarskiej II kościoła (2 faza) - liść w kolorze błękitnym, odsłonięty przy łuku tęczowym po stronie północnej, fot. I. Brzostowska, $2012 \mathrm{r}$.

11. Toruń, kościół pw. Św. Jana Chrzciciela i Św. Jana Ewangelisty, korpus nawowy, filar pierwszy od zachodu w rzędzie południowym (pierwotnie półfilar przy ścianie zachodniej), dekoracja malarska II kościoła w formie wici roślinnej, fot. I. Brzostowska, $2011 \mathrm{r}$.

12. Toruń, kościół pw. Św. Jana Chrzciciela i Św. Jana Ewangelisty, korpus nawowy, dekoracja malarska II kościoła na pierwszym od wschodu półfilarze w nawie południowej, fot. I. Brzostowska, $2011 \mathrm{r}$.

13. Toruń, kościół pw. Św. Jana Chrzciciela i Św. Jana Ewangelisty, korpus nawowy, filar pierwszy od zachodu w rzędzie północnym (pierwotnie półfilar przy ścianie zachodniej), dekoracja malarska II kościoła - wielki wątek, fot. I. Brzostowska, 2011 r. 


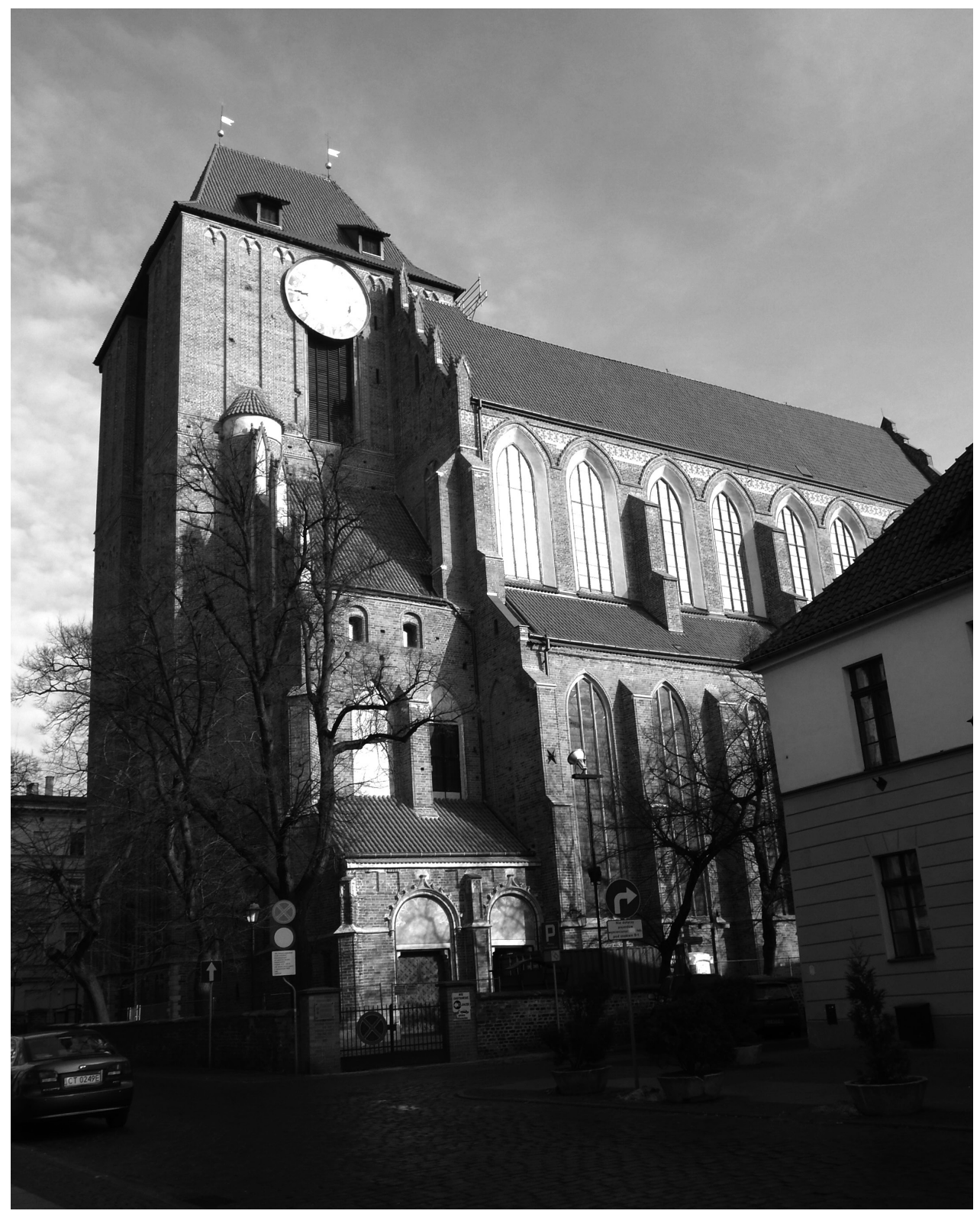

Il. 1 Toruń, kościół pw. Św. Jana Chrzciciela i Św. Jana Ewangelisty, widok od pd.-zach., fot. M. Gałązka-Nikonov, 2011 r. 


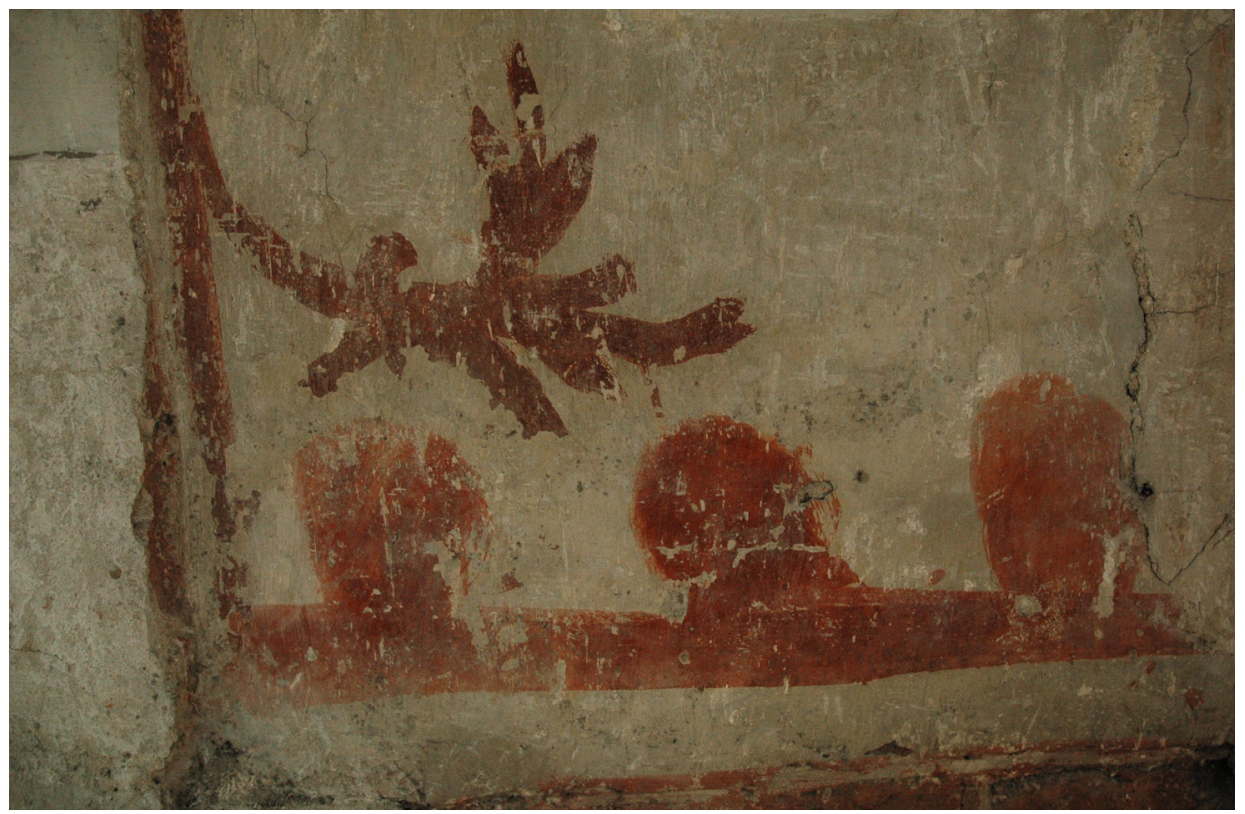

Il. 2 Toruń, kościół pw. Św. Jana Chrzciciela i Św. Jana Ewangelisty, korpus nawowy, ściana południowa, dekoracja malarska tzw. II kościoła, 1 poł. XIV w.: 1 faza - czołganki, 2 faza - liście, fot. I. Brzostowska, $2011 \mathrm{r}$.

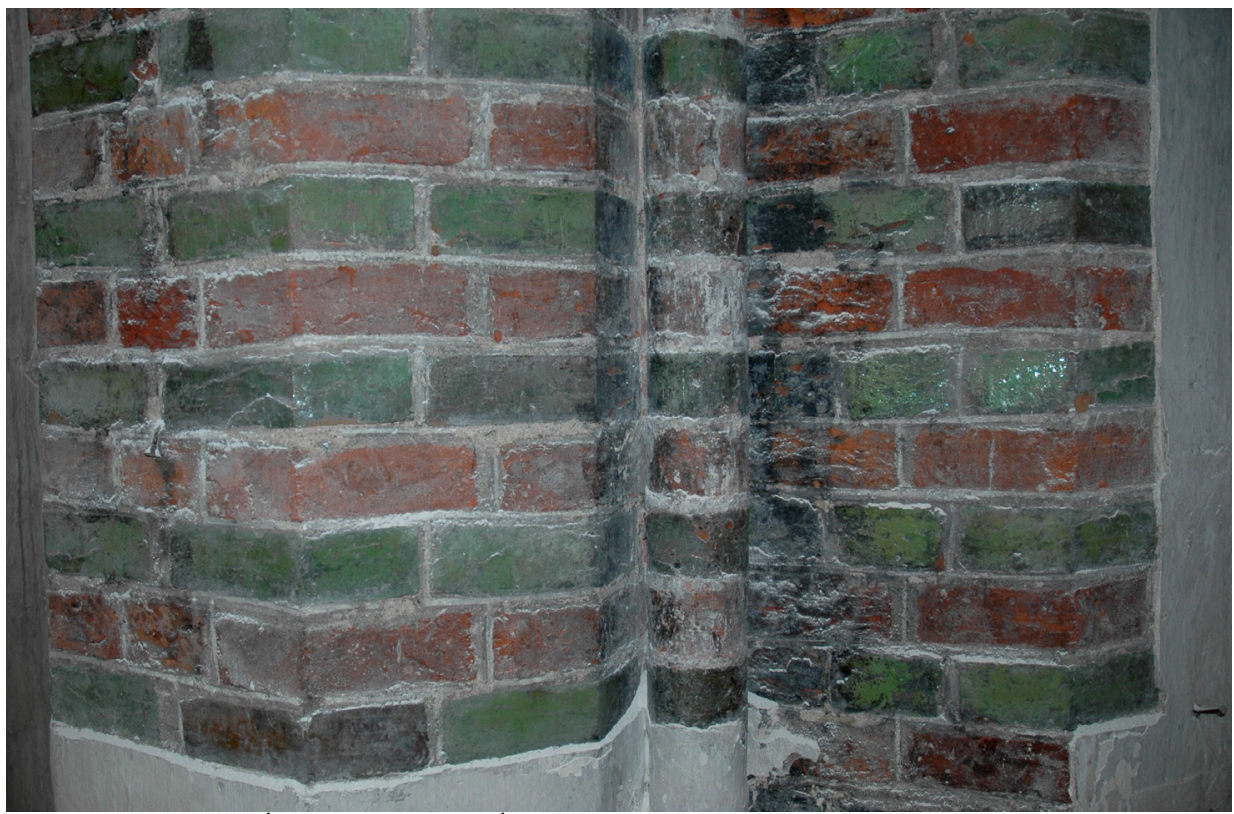

Il. 3 Toruń, kościół pw. Św. Jana Chrzciciela i Św. Jana Ewangelisty, korpus nawowy, ściana południowa - fragment pierwotnej arkady łączącej nawę południową z aneksem przywieżowym, fot. I. Brzostowska, $2012 \mathrm{r}$. 


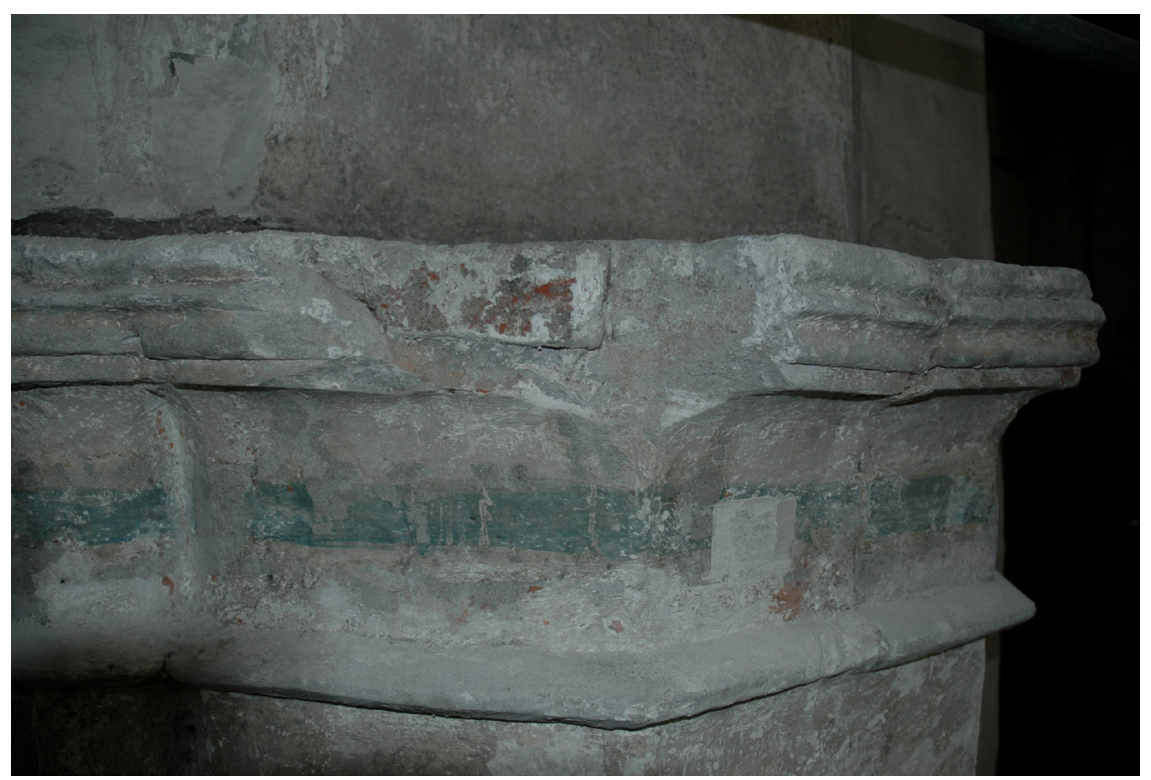

Il. 4 Toruń, kościół pw. Św. Jana Chrzciciela i Św. Jana Ewangelisty, korpus nawowy, filar środkowy w rzędzie północnym, partia dolna pochodząca z II kościoła - dekoracja z zielonej glazurowanej cegły, fot. I. Brzostowska, $2011 \mathrm{r}$.

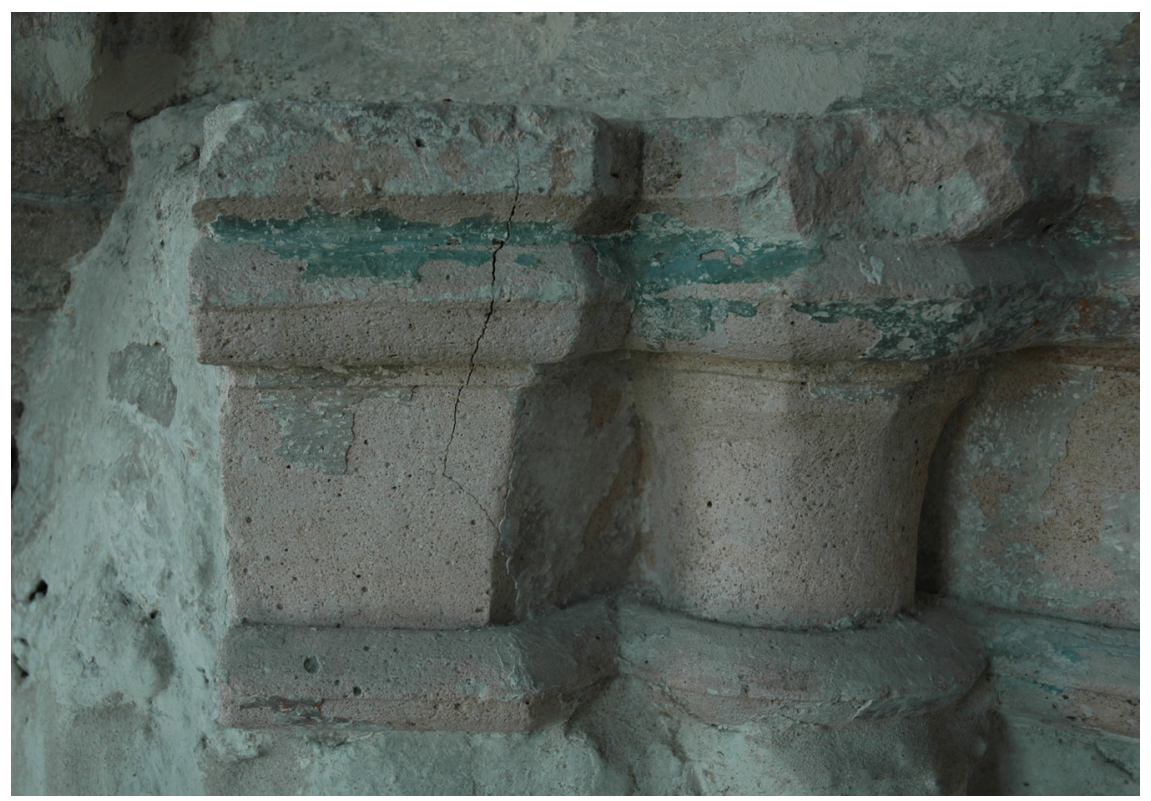

Il. 5 Toruń, kościół pw. Św. Jana Chrzciciela i Św. Jana Ewangelisty, korpus nawowy, ściana północna, strefa kapitelowa półfilara pomiędzy obecnymi kaplicami Św. Ignacego Loyoli i Św. Józefa, dekoracja malarska II kościoła, fot. I. Brzostowska, 2011 r. 


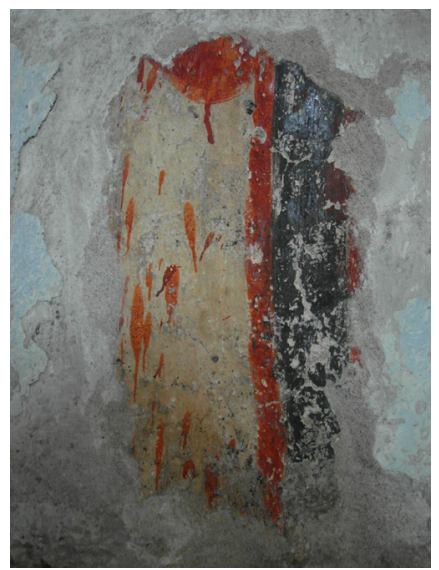

Il. 6 Toruń, kościół pw. Św. Jana Chrzciciela i Św. Jana Ewangelisty, korpus nawowy, strefa kapitelowa filara pierwszego od wschodu w rzędzie północnym, dekoracja malarska II kościoła, fot. I. Brzostowska, $2011 \mathrm{r}$.

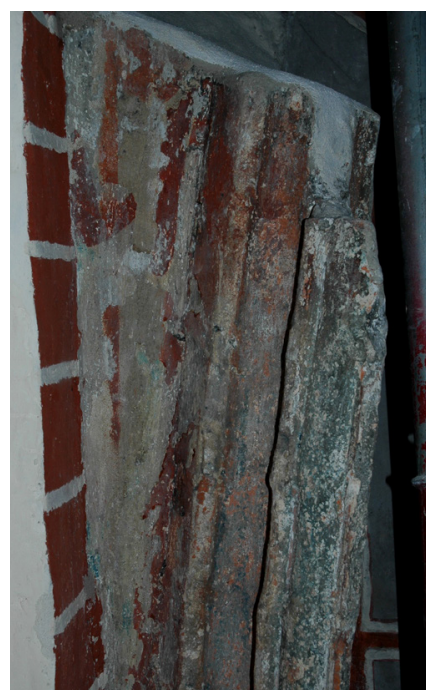

Il. 8 Toruń, kościół pw. Św. Jana Chrzciciela i Św. Jana Ewangelisty, korpus nawowy, dekoracja malarska II kościoła (1 faza) zachowana nad łukiem tęczowym (stan po konserwacji), fot. I. Brzostowska, $2012 \mathrm{r}$.

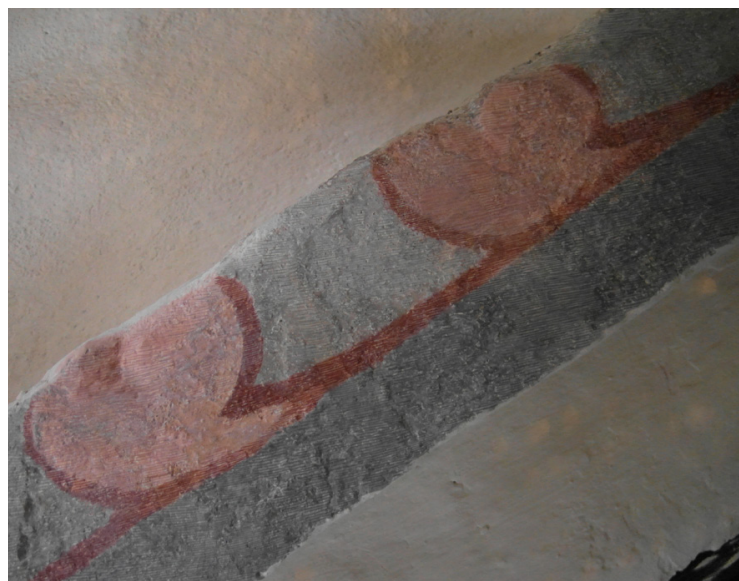

Il. 7 Toruń, kościół pw. Św. Jana Chrzciciela i Św. Jana Ewangelisty, korpus nawowy, ściana południowa, fragment dekoracji malarskiej II kościoła (1 faza) odsłonięty na skutym spływie sklepiennym, ponad półfilarem pomiędzy obecnymi kaplicami Św. Stanisława Kostki i Matki Boskiej Nieustającej Pomocy, fot. I. Brzostowska, 2011 r.

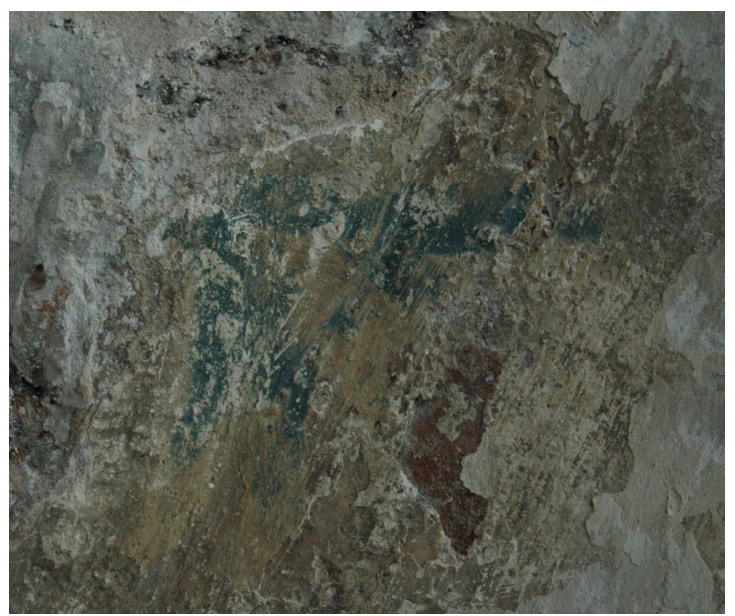

Il. 9 Toruń, kościół pw. Św. Jana Chrzciciela i Św. Jana Ewangelisty, korpus nawowy, spływ sklepienny II kościoła z zachowaną pierwotną dekoracją malarską, fot. I. Brzostowska, $2011 \mathrm{r}$. 


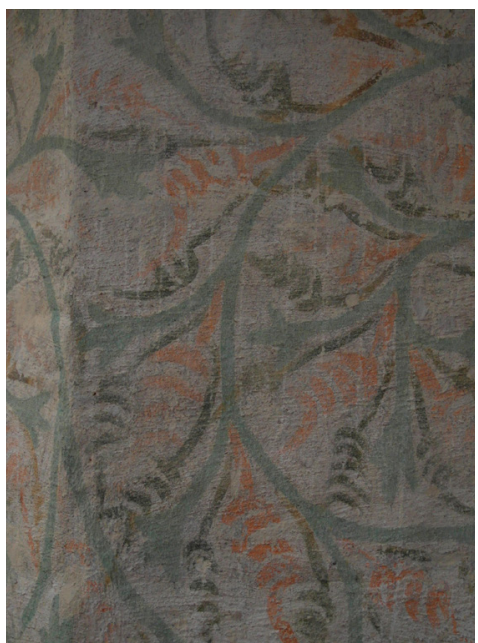

Il. 10 Toruń, kościół pw. Św. Jana Chrzciciela i Św. Jana Ewangelisty, korpus nawowy, filar pierwszy od zachodu w rzędzie południowym (pierwotnie półfilar przy ścianie zachodniej), dekoracja malarska II kościoła w formie wici roślinnej, fot. I. Brzostowska, $2011 \mathrm{r}$.

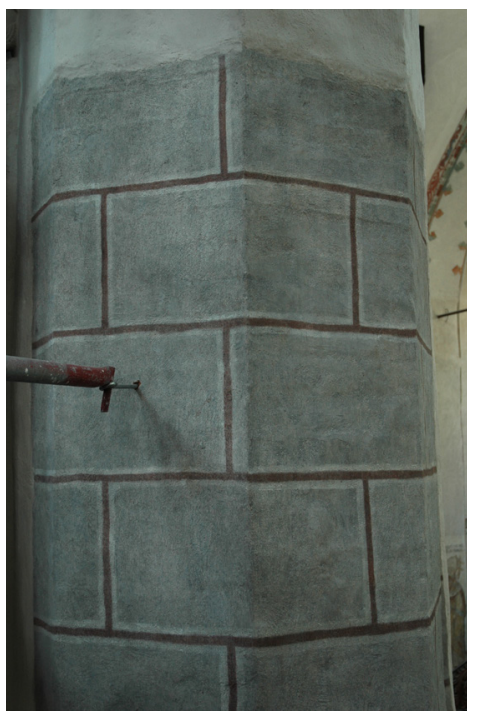

Il. 12 Toruń, kościół pw. Św. Jana Chrzciciela i Św. Jana Ewangelisty, korpus nawowy, filar pierwszy od zachodu w rzędzie północnym (pierwotnie półfilar przy ścianie zachodniej), dekoracja malarska II kościoła - wielki wątek, fot. I. Brzostowska, $2011 \mathrm{r}$.

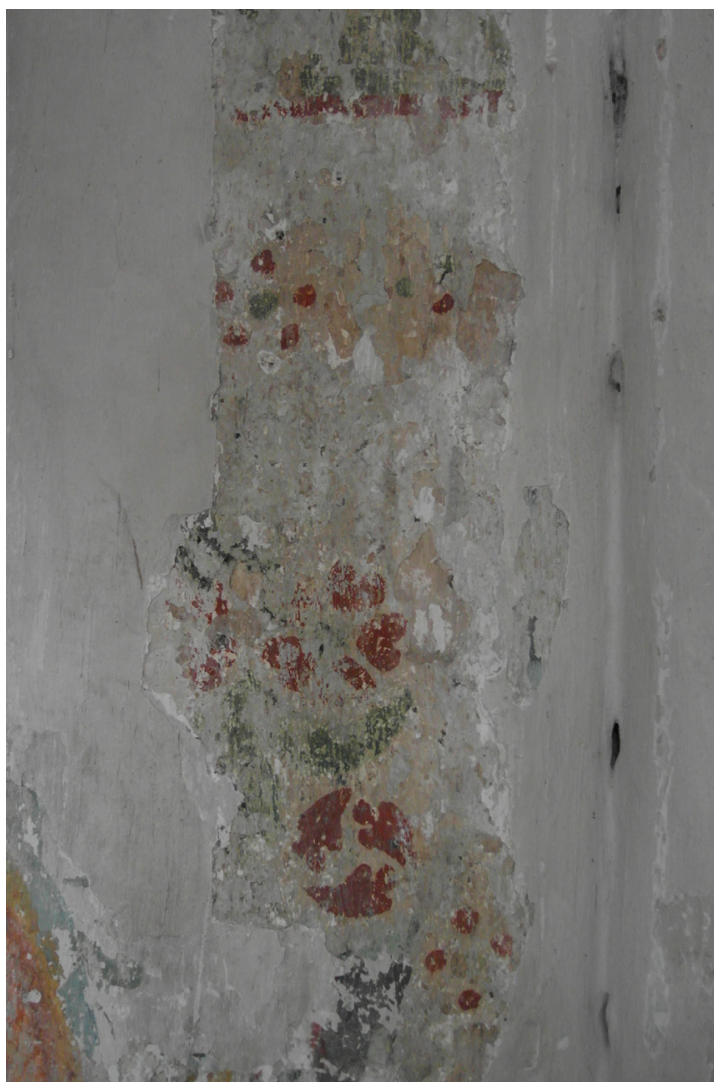

Il. 11 Toruń, kościół pw. Św. Jana Chrzciciela i Św. Jana Ewangelisty, korpus nawowy, dekoracja malarska II kościoła na pierwszym od wschodu półfilarze w nawie południowej, fot. I. Brzostowska, $2011 \mathrm{r}$. 